\title{
Cuban Contributions to Latin American Clinical Care and Research on Diabetes and Pregnancy
}

\author{
Jeddú Cruz-Hernández MD MS, Antonio Márquez-Guillén MD PhD, Jacinto Lang-Prieto† MD, Ileydis Iglesias-Marichal MD MS
}

\begin{abstract}
Cuban participation in and contributions to education, medical care and research on diabetes and pregnancy in Latin America dates back to the 1970s when the Latin American Diabetes Association was founded. The Cuban health system and its professionals recognized early the problems presented by diabetes during pregnancy for the health of an expectant mother and her children and assimilated and disseminated important lessons that became influential in the region. These included: importance of adopting a program within primary health care that offers national coverage for diabetic pregnant women, with a special focus on pre-conception monitoring of diabetic women; benefits of defining a specific range for application of a fasting glucose test to identify risk of gestational diabetes through selective screening for the disease; using insulin to treat gestational diabetes; controlling excessive weight at the beginning and during pregnancy; and underscoring the importance of interdisciplinary treatment of diabetes in pregnancy. The goal was to improve care and research in reproductive health for diabetic pregnant women and their children in Cuba.
\end{abstract}

KEYWORDS: Gestational diabetes, pregnancy, Latin America, Cuba

\section{INTRODUCTION}

Systematic activities in specialized medical care and research on diabetes in pregnancy were formalized in Latin America with the creation of the Latin American Diabetes Association (ALAD), founded in 1970 in Buenos Aires, Argentina. ALAD's mission is to improve the quality of medical care, education and research regarding diabetes mellitus (DM) in the region, including diabetes during pregnancy.[1,2]

When ALAD was founded, morbidity and mortality from diabetes in Latin America was increasing, its steady growth leading to a significant public health problem for the region. Disease prevalence in different countries was reported at 1.2\%-7.3\%, and PAHO's Inter-American Investigation of Mortality estimated regional mortality at $2.6 \%$ with several countries showing an upward trend.

\section{IMPORTANCE}

Cuban professionals have made important theoretical and methodological contributions to the topic of diabetes in pregnancy in Latin America, leading to improved medical care for diabetic pregnant women. This article reviews these contributions and highlights their significance.
Diabetes prevalence in Cuba was $3.8 \%$ in 1970 and the mortality rate rose from 2.4 to 10.5 per 100,000 population from 1910 to 1971.[3] While statistics are scarce from those years on diabetes in pregnancy, it was reported that women who were diabetic before becoming pregnant-pregestational diabetes-could present with complications during pregnancy (miscarriages, congenital defects, fetal macrosomia, preeclampsia, fetal death, preterm and dystocic births, etc). It was also reported that such complications were more common in cases when treatment and control of the disease was inadequate.[4-6] In the 1960s, in Cuba and worldwide, diabetes in pregnancy affected approximately 1 in 1000 pregnant women.[7] In 1965, a study conducted in a Cuban maternity hospital corroborated the association between diabetes in pregnancy and fetal mortality.[8]

In the 1990s, gestational diabetes mellitus (GDM) affected a notable proportion of pregnant women in the United States and Latin America, with a prevalence in Latin America ranging from $1 \%$ to 14\%.[9-11] Cuba's first study on GDM prevalence, conducted in 1996 in a Havana community polyclinic catchment area, showed that $4.5 \%$ of pregnant women there suffered from the disease. While the study's limited sample could not be used to make inferences regarding national prevalence, it did provide an initial approximation to the problem and suggested that GDM could be a major health challenge for the country.[12] In 2005, WHO reported that GDM was $0.77 \%$ in Latin America, while Cuba's rate was the highest of all countries included in the study (1.75\%).[11]

To mitigate this problem, Cuban specialists conducted research and organized specialized health services. They worked to improve the quality of specialized medical care, research and education regarding diabetes in pregnancy through theoretical and methodological contributions.

\section{DEVELOPMENT}

When ALAD was founded, specialized medical practice for diabetes in pregnancy had been set up in Cuba; and in the early 1970s the first Diabetes and Pregnancy Service was established at the Ramón González Coro Maternity Hospital.[13] This specialized clinic improved the ability of Cuban specialists to continue making scientific and methodological contributions to the scientific community regarding the care and management of women with pregestational diabetes and GDM.

The founding of a Latin American association where experts from different countries could share information and experiences occurred in a moment when the disease's prevalence and incidence were rising. This created a favorable context for diabetes in pregnancy to be recognized as a particular problem demanding attention due to its repercussions on the reproductive health of women and the health of their children. Cuban professionals who were diagnosing and treating pregnant women with diabetes and carrying out research on the subject 
appreciated that ALAD offered an opportunity to disseminate the results of their work and extend them to other Latin American countries.

Cuban specialists found that pregnant diabetic women more frequently gave birth to children with congenital malformations (3:1 ratio).[14] Perinatal mortality was also higher among children of women with diabetes in pregnancy.[8,15] Such results confirmed findings by authors in other countries $[5,6,16]$ and enabled researchers to design guidelines for the metabolic and obstetric management of diabetes in pregnant women.[15]

Among these guidelines was insulin as the treatment of choice for diabetes during pregnancy, even if women took oral hypoglycemic drugs before pregnancy. The main argument put forward by the Cuban professionals was evidence of teratogenic effects of some oral hypoglycemic medications such as tolbutamide[17] and occurrence of neonatal hypoglycemia associated with its use, already documented by researchers in other countries.[18] For this therapy, they initially proposed a treatment regimen (pre-hypoglycemic) based on the Roversi gestational diabetes regimen, $[19,20]$ which was later replaced by the intensive or multi-dose insulin treatment plan currently used in Cuba. The regimen consists of administering rapid-action insulin before meals and intermediate-action insulin at night, ensuring optimal glycemic control and best pregnancy outcomes.[21,22] In 2007, ALAD's Latin American Consensus on Diabetes and Pregnancy (Consenso Latinoamericano de Diabetes y Embarazo de la ALAD) established insulin therapy as the standard for treatment of diabetes during pregnancy.[23]

Cuban specialists participated in preparing ALAD's clinical care guides for pregnant diabetics, with particular contributions to pre-conception care standards for diabetic women considering pregnancy, as well as control of their diabetes during pregnancy.[24] The theoretical and methodological foundation of Cuban professionals' contributions arose from their ongoing experience in monitoring and treating diabetic pregnant women in the Diabetes and Pregnancy Service of the Ramón González Coro Maternity Hospital and, from 1992, at the pre-conception care clinic for diabetic women at the Diabetes Care Center of Cuba's National Endocrinology Institute in Havana.[13]

Among others, their results showed the adverse effects of obesity at the start of pregnancy or excessive weight gain during pregnancy.[25-27]

Cuba's contribution to ALAD's care recommendations for pregnant diabetics once again consisted of developing guidelines for preconception care for diabetic women.[28] The first reports on the benefits of this care were published in the early 1990s [29-31] and introduced in Cuba in 1992, with the founding of a preconception clinic for diabetic women in Havana, the first of this type in the country.[13] Comparing pregnancy outcomes of diabetic women who had received this specialized primary health care and those who had not showed significant differences in prevalence of congenital defects (0.9\% vs. 9.6\%, respectively) and in perinatal mortality (0.9\% vs. $7.0 \%)$. Researchers presented new results on the association of initial excess weight (body mass index $\geq 26.1 \mathrm{~kg} / \mathrm{m}^{2}$ ) and excessive weight gain during pregnancy, with macrosomia and other adverse outcomes for pregnant diabetic women and their newborns. They also suggested preconception care for women with pregestational diabetes, laser therapy to treat diabetic retinopathy during pregnancy, and strict obstetric followup and antepartum fetal surveillance in pregnancies complicated by DM, among other recommendations.[32-34]

The benefits of preconception care, inserted into primary health care, were subsequently extended throughout Cuba, with national coverage of the Cuban Diabetes and Pregnancy Program (PCDE) launched in 2001.[35] Not all Latin American countries were able to establish such services, so Cuba maintained a leading role in management of diabetic pregnancies in the region.

Cuba was also in the leadership of the International Diabetes Federation's Working Group on Diabetes and Women in the South American/Central American/Caribbean Region when the Latin American and Caribbean Association of Sexual and Reproductive Health in Diabetes was recognized as an International Association of Diabetes and Pregnancy Study Groups (IADPSG)-affiliated scientific organization. Major actions carried out under this leadership include the proposal for Latin American member countries to create national health programs on diabetes and pregnancy, with Cuba's PCDE as a reference point. This proposal was based on the benefits attained by diabetic Cuban women through attention to the reproductive risk associated with diabetes, including preconception care for diabetic women and transdisciplinary care for pregnant women with diabetes.[13]

In 2007, Cuban specialists proposed ALAD recommend screening for congenital defects in fetuses of diabetic expectant mothers during the first half of pregnancy and for fetal macrosomia from the 28th week, both by ultrasound, as well as periodic obstetric monitoring of fetal health from the 34th week. These recommendations were included in a consensus document. Additional Cuban contributions included emphasis on the benefits of applying WHO's GDM diagnostic criteria,[23] which were adopted by ALAD with some modifications and are now being implemented.[36]

Cuban specialists demonstrated the value of fasting glycemia to screen for GDM and impaired glucose tolerance, in contrast to recommendations from the American Diabetes Association, namely using a glucose tolerance test with a load of $50 \mathrm{~g}$ of glucose. The range proposed as a risk marker for the disease was 4.4-5.5mmol/L.[37] This standard was included in the Latin American Consensus on Diabetes and Pregnancy in 2008 and in Cuba's PCDE disease-screening protocol.[23,35,37]

In 2014, the coverage of the 19 services of the transdisciplinary diabetes care network in pregnancy was $100 \%$ of mothers with gestational diabetes; $41 \%$ of whom were women undergoing preconception care for pregestational diabetes. Perinatal mortality in children of diabetic mothers was $4.8 \%$, congenital defects appeared in $4.3 \%$ of children in the program, and mortality in women with GDM was 24 per 100,000 population. Cuba was recognized by $\mathrm{PAHO}$ as one of the few countries in Latin America with a national program that included health promotion activities for diabetic women of reproductive age aimed at preventing GDM and reduce unfavorable pregnancy outcomes, a growing body of research in diabetes 
and pregnancy, and training of some 60 healthcare providers in this field. $[38,39]$

Cuban specialists showed that GDM also entails high risk of fetal macrosomia (one of the most common complications affecting children of diabetic mothers), and underscored the importance of early GDM diagnosis and intervention during pregnancy to prevent adverse outcomes.[40] They also made the case for diagnostic testing in the 26th week of pregnancy instead of the established practice of testing between the 28th to 32 nd week, thus allowing for earlier intervention. This proposal was approved by ALAD[36] and introduced in Cuba in 2017.[41]

In 2015, newborns of Cuban diabetic mothers had a low percentage of congenital defects $(2.5 \%)$. Perinatal mortality was also low $(2.9 \%)$ for newborns of women with pregestational diabetes (2008-2015). Other events with low relative frequencies in women with GDM in 2015 were: fetal macrosomia (6.0\%), premature births (3.1\%), low birth weight (4.0\%), perinatal mortality $(0.6 \%)$, and maternal mortality $(0.0 \%)$. Today, Cuba remains one of the few countries in Latin America with consistent and systematic preconception care, since the PCDE provides preconception care for women with pregestational diabetes, and prenatal care for diabetic women, diagnosis of GDM, and longterm monitoring of these women and their children.[42]

\section{CONCLUSIONS}

Cuban specialists have played an important role in early detection and prevention of congenital defects in children of diabetic mothers and on strict obstetric monitoring, prenatal fetal surveillance and identification of risk factors for fetal macrosomia, the most common complication in diabetic pregnancies. They recommended use of insulin for diabetic pregnancy management with specific treatment plans and promoted preventive use of insulin therapy in GDM. This contributed to significant improvements in health indicators of diabetic pregnant women in Cuba. Cuban proposals also led to new regional consensus recommendations in areas such as weight control according to initial weight and weight gain, as well as new guidelines for applying fasting blood glucose tests to screen for GDM.

The organization of health services under a specific national diabetes and pregnancy program inserted into primary health care proved to be an effective strategy in monitoring and controlling diabetes before conception, during pregnancy, and up to the time of delivery, an experience shared regionally.

Through dissemination of their research results and knowledge gained from their experience in management of women of childbearing age and diabetic women during pregnancy, Cuban specialists have made important contributions to defining standards and procedures to ALAD's, in treatment of diabetic pregnant women. $-1 /$ -

\section{REFERENCES}

1. García de los Ríos M. Historia de la Asociación Latino Americana de Diabetes (ALAD). 19702010. Rev Chil Endocrinol Diabetes [Internet]. 2011 [cited 2018 Sep 3];4(1):61-3. Available at: http://www.revistasoched.cl/1_2011/11-1_2011 .pdf. Spanish.

2. Cardonnet LJ. El pasado de la Asociación Latinoamericana de Diabetes. Rev ALAD. 1993;I (2):80-2. Spanish.

3. Valiente S, Behnke J. La diabetes mellitus como problema de salud en la América Latina y el Caribe. In: Grupo de Estudio sobre Diabetes Mellitus, editor. Publicación Científica No. 312. OPS. Oficina Sanitaria Panamericana, Oficina Regional de la OMS. Washington, D.C.: Pan American Health Organization; 1975. p. 19-27. Spanish.

4. Gabbe SG. A story of two miracles: the impact of the discovery of insulin on pregnancy in women with diabetes mellitus. Obstet Gynecol. 1992;79(2):295-9.

5. Hadden DR. History of diabetic pregnancy. In: Moshe $\mathrm{H}$, Jovanovic L, Di Renzo GC, De Leiva A, Langer $\mathrm{O}$, editors. Textbook of Diabetes and Pregnancy. London: Informa Healthcare; 2008 Mar 4. p. 1-8.

6. Karter H. The early years. In: Karter H. A history of diabetes in pregnancy. The impact of maternal diabetes on offspring prenatal development and survival. Springer: New York; 2012. p. 7-9.

7. Márquez A, Valdés L. Diabetes y embarazo. En: Mateo de Acosta O. Diabetes Mellitus. Havana: Ciencia y Técnica; 1971. p. 355-92. Spanish.

8. Márquez A. Síndrome prediabético, su importancia como causa de muerte fetal en nuestro hospital. Rev Cubana Med. 1965:4:22-39. Spanish.

9. Coustan DR. Gestational diabetes. In: National Diabetes Data Group, editor. Diabetes in America. Maryland: National Institutes of Health and National Institute of Diabetes and Digestive and Kidney Diseases; 1995. p. 703-17.

10. Lawrence JM. Prevalence of GDM. In: Kim C, Ferrara A, editors. Gestational diabetes mellitus during and after pregnancy. Springer: London 2010. p. 53-69.

11. Voto LS, Mattioli MJ, Uranga M. Gestational Diabetes in Latin America. In: Moshe $\mathrm{H}$, Jovanovic L, Di Renzo GC, De Leiva A, Langer O, editors. Textbook of Diabetes and Pregnancy. London: Informa Healthcare; 2008 Mar 4. p. 132-4.

12. Márquez A, Aldana D, Rodríguez BR, González ME, Lang J, Pérez L, et al. Prevalencia de diabetes gestacional en un área de salud de Ciudad de La Habana. Rev ALAD. 1996; IV(2):75-80. Spanish.

13. Cruz J, Márquez Guillén A. Historia de la diabetes y embarazo en Cuba después de 1959. Rev Cubana Salud Pública [Internet]. 2019 Dec 31 [cited 2020 Jan 22];45(4). Available at: http://www. revsaludpublica.sld.cu/index.php/spu/article/ view/1701/1339. Spanish.

14. Valdés LA, Márquez A, Santana O, Rodríguez B, Cuevas E, Sánchez C. Las malformaciones congénitas en hijos de madres diabéticas (estudio de 1064 nacimientos consecutivos): II parte y final. Rev Cubana Obstet Ginecol. 1991;17(2):86-100. Spanish.

15. Márquez A. Diabetes y embarazo. En: Orientaciones Terapéuticas. Ginecología No. 1. Havana: National Information Center for Medial Sciences (CU); 1968. Spanish

16. Karter $\mathrm{H}$. The framework. In: Karter $\mathrm{H}$, editor. A history of diabetes in pregnancy. The impact of maternal diabetes on offspring prenatal development and survival. Springer: New York; 2012. p. 3-6.

17. Márquez A, Valdés LA. Valoración del efecto teratogénico de los compuestos orales hipoglicemiantes en el tratamiento de la gestante diabética. Rev Cubana Obstet Ginecol. 1977;3(3):231-40. Spanish.

18. Langer $\mathrm{O}$. Oral anti-diabetic agents in pregnancy: Their time has come. In: Moshe $\mathrm{H}$, Jovanovic L, Di Renzo GC, De Leiva A, Langer O, editors. Textbook of Diabetes and Pregnancy. London: Informa Healthcare; 2008 Mar 4. p. 217-27.
19. Roversi GD, Gargiulo M, Nicolini U, Pedretti E Marini A, Barbarani V, et al. A new approach to the treatment of diabetic pregnant women. Report of 479 cases seen from 1963 to 1975. Am J Obstet Gynecol [Internet]. 1979 [cited 2020 Jan 22];135:567-76. Available at: https://doi .org/10.1016/S0002-9378(16)32978-7.

20. Roversi GD, Gargiulo M, Nicolini U, Ferrazzi E Pedretti E, Gruft L, et al. Maximal tolerated insulin therapy in gestational diabetes. Diabetes Care [Internet]. 1980 [cited 2020 Jan 22];3(3):489-94. Available at: https://doi.org/10.2337/diacare.3.3 .489

21. Valdés L, Márquez A, Rodríguez BR. Tratamiento de la diabetes gestacional: dieta o dieta e insulina. Rev ALAD. 1998; VI(2):110. Spanish.

22. Lang J, Márquez A, Santana O, González MA, Zaldívar O, Rodríguez BR, et al. Estudio comparativo de tres esquemas de tratamiento insulínico en la gestante diabética. Spanish. Rev ALAD. 1998; $\mathrm{VI}(2): 110$.

23. Colectivo de autores. Consenso Latinoamericano de Diabetes y Embarazo. Rev ALAD [Internet]. 2008 [cited 2018 Sep 3];XVI(2):55-69. Available at: http://www.revistaalad.com/files/08 02concensos_al.pdf. Spanish.

24. Latin American Diabetes Association (ALAD) Normas de atención a la diabética embarazada Seminario ALAD. Mendoza. Argentina. 9 y 10 de mayo de 1994. Rev ALAD. 1994;II(2):6-26. Spanish.

25. Rodríguez BR, Valdés L, Pérez J, Márquez A, Lang J, González MA. Efecto del peso al inicio del embarazo sobre la morbilidad y la mortalidad materna y perinatal en diabéticas gestacionales. Rev Cubana Endocrinol [Internet]. 1997 [cited 2018 Sep 3];8(1):79. Available at: http://bvs.sld .cu/revistas/end/vol8_1_97/end07197.pdf. Spanish.

26. Rodríguez BR, Valdés L, Pérez J, González MA, Lang J, Llibre N, et al. Relación entre la ganancia de peso materna y algunas eventualidades 
obstétricas y perinatales en diabéticas gestacionales. Rev Cubana Endocrinol [Internet]. 1997 [cited 2018 Sep 3];8(1):80. Available at: http:// bvs.sld.cu/revistas/end/vol8_1_97/end07197 pdf. Spanish.

27. Rodríguez B, Valdés L, Castellanos L, Festaris A, Santana O, Santurio A, et al. La malnutrición materna por exceso o por defecto en diabéticas gestacionales. Resultados maternos y perinatales. Rev ALAD [Internet]. 2007 [cited 2018 Sep 3];XV(3):130. Available at: http://www.revistaalad .com/pdfs/070304ec.pdf. Spanish.

28. Colectivo de autores. Consenso ALAD sobre la atención a la diabética embarazada aprobado en Mendoza, 1994 y modificado en Cancún, 1997. Rev ALAD. 1997;V(4):223-34. Spanish.

29. Steel JM, Johnstone FD, Hepburn DA, Smith AF. Can prepregnancy care of diabetic women reduce the risk of abnormal babies? BMJ. 1990 Nov 10;301(6760):1070-4.

30. Rosenn B, Miodovnik M, Combs A, Khoury J, Siddigi TA. Pre-conception management of insulin-dependent diabetes: improvement of pregnancy outcome. Int J Gynecol Obstet. 1991 May;38(1):846-9.

31. Kitzmiller JL, Gavin LA, Gin GD, Jovanovic-Peterson L, Main EK, Zigrang WD. Preconception care of diabetes. Glycemic control prevents congenital anomalies. JAMA. 1991 Feb 13;265(6):731-6.

32. Márquez A, Lang J. Salud reproductiva y diabetes mellitus. Rev Cubana Endocrinol. 2000;11(2):61-2. Spanish.

33. Márquez A. Salud reproductiva en diabetes. I Congreso Internacional de Salud Reproductiva en Diabetes Mellitus "SAREDIA 2000". Varadero, Cuba, 14 de noviembre de 2000. Rev Cubana Endocrinol. 2000;II(Suppl):7. Spanish.

34. Sociedad Cubana de Endocrinología, Sociedad Cubana de Diabetes, Sociedad Cubana de Medicina y Salud Reproductiva, Instituto Nacional de Endocrinología. I Congreso Internacional de Salud Reproductiva en Diabetes Mellitus "SAREDIA 2000"; Varadero, Cuba. Carteles. Rev Cubana Endocrinol. 2000;II(Suppl):23-77. Spanish.

35. Valdés Amador L, Lang Prieto J, Rodríguez Anzardo BR, Santana Bacallao O, Zaldívar Guer- ra O, Santuario Gil A, et al. Programa Nacional de Atención a la Gestante con Diabetes [Internet]. Havana: National Institute of Endocrinology (CU); 2001 [cited 2018 Sep 3]. 10 p. Available at: http://files.sld.cu/boletincnscs/files/2009/07/ respub2009drmarquezguillen.pdf. Spanish.

36. Colectivo de autores. Guías de diagnóstico y tratamiento de diabetes gestacional. ALAD 2016. Rev ALAD [Internet]. 2016 [cited 2019 Jan 19];6:155-69. Available at: http://www.revistaalad .com/files/alad v6 n4 155-169.pdf. Spanish.

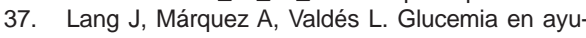
nas como instrumento en la pesquisa de la diabetes gestacional. Rev ALAD [Internet]. 2007 [cited 2018 Jul 19];XV(3):130. Available at: http://www revistaalad.com/pdfs/070304ec.pdf. Spanish.

38. Pan American Health Organization; World Health Organization. Hiperglucemia y embarazo en Las Américas. Informe final de la Conferencia Panamericana sobre Diabetes y Embarazo. Lima (Perú), 8-10 septiembre de 2015 [Internet]. Washington, D.C.: Pan American Health Organization; 2016 [cited 2018 Sep 3]. Available at: http://iris.paho.org/xmlui/bitstream/ handle/123456789/28207/9789275318836_spa .pdf. Spanish.

39. Cruz J, Lang J, Márquez A, Valdés L. Care for pregnant diabetics in Cuba: achievements and challenges. MEDICC Rev [Internet]. 2013 Jul [cited 2020 Jan 22];15(3):38-41. Available at: http:// mediccreview.org/wp-content/uploads/2018/04/ mr_316.pdf

40. Poster presentations. Session C: GDM management and follow up. In: International Association of the Diabetes and Pregnancy Study Groups (IADPSG). Scientific IADPSG Meeting 2016 March 21-23; Buenos Aires, Argentina. Abstracts of the lectures, hot topics, workshop, clinical updates, oral presentations and poster presentations presented at IADPSG Meeting 2016. Rev Soc Argentina Diab [Internet]. 2016 [cited 2018 Sep 3];50(Special issue - Scientific IADPSG Meeting 2016):46. Available at http://www.diabetes.org.ar/media/attachments/ 2018/01/29/especial-iadpsg.pdf

41. Cruz J, Piloto M. Segundo Consenso Cubano de Diabetes y Embarazo. Rev Cubana Endo- crinol [Internet]. 2018 [cited 2020 Jan 22];29(1). Available at: http://www.revendocrinologia.sld .cu/index.php/endocrinologia/article/view/97/86. Spanish.

42. Cruz J. Acta de la II Conferencia Panamericana de Diabetes y Embarazo (CPDE). Diabetes y Embarazo en América Latina. Havana: Pan Amerian Health Organization; World Health Organization; 2016. Spanish.

\section{THE AUTHORS}

Jeddú Cruz-Hernández (Corresponding author: celsocruz@infomed.sld.cu), physician with dual specialties in family medicine and endocrinology and master's degrees in comprehensive women's health care, atherosclerosis research and diagnostic procedures in primary health care. Professor and associate researcher, and head of Diabetes and Pregnancy Working Group, Center for Comprehensive Diabetes Care of the National Endocrinology Institute (INEN), Havana, Cuba.

Antonio Márquez-Guillén, endocrinologist with a doctorate in medical sciences. General coordinator, Cuban Program on Diabetes and Pregnancy (PCDE). Full professor and senior researcher, INEN, Havana, Cuba.

Jacinto Lang-Prieto†, endocrinologist. Professor and associate researcher, INEN, Havana, Cuba.

Ileydis Iglesias-Marichal, physician with dual specialties in family medicine and endocrinology, with a master's degree in urgent care. Director, INEN, Havana, Cuba.

Submitted: August 5, 2019

Approved for publication: October 4, 2020 Disclosures: Jeddú Cruz-Hernández is the current $A L A D$ delegate for Cuba. 